\title{
Kadar Prokalsitonin dan Interleukin-6 sebagai Penanda Prognostik pada Pasien Pneumonia dengan Sepsis
}

\section{Procalcitonin and Interleukin-6 Levels as Prognostic Biomarker in Pneumonia Patients with Sepsis}

\author{
Sylvia Sagita $S^{1}$, Ngakan Putu P $^{1}$, Yani Jane $S^{1}$, Harun Al Rasyid ${ }^{2}$ \\ ${ }^{1}$ Departemen Pulmonologi dan Kedokteran Respirasi Rumah Sakit Umum Daerah Dr Saiful Anwar Malang \\ ${ }^{2}$ Departemen Ilmu Kesehatan Masyarakat Fakultas Kedokteran Universitas Brawijaya Malang
}

\begin{abstract}
ABSTRAK
Pneumonia merupakan sepuluh besar kasus rawat inap dengan tingkat kematian $7,6 \%$. Pneumonia dengan sepsis membutuhkan terapi suportif dan perawatan intensif karena tingkat kematian tinggi. Untuk memperbaiki kualitas perawatan dan hasil terapi yang lebih baik, perlu pengkajian dini diagnostik maupun prognostik. Prokalsitonin (PCT) dan Interleukin-6 (IL-6) merupakan penanda infeksi berat dan sepsis. Tujuan penelitian ini untuk menganalisa apakah PCT dan IL-6 dapat digunakan bersama-sama untuk menentukan prognosis pasien pneumonia dengan sepsis dalam hubungannya dengan status mortalitas pada hari ke-30. Penelitian kohort dilakukan pada Oktober 2018 dilakukan di Rumah Sakit Saiful Anwar, Malang, melibatkan 40 pasien pneumonia dengan sepsis tanpa diabetes, kanker, HIV dan kehamilan. Sequential Organ Failure Assesment (SOFA) score dihitung dan sampel darah diambil pada hari ke-0 dan ke-5 perawatan untuk mengukur kadar PCT dan IL-6. Status mortalitas pasien dilihat pada hari ke-30 sejak masuk rumah sakit. Dari 40 pasien, 23 pasien hidup (57,5\%) dan 17 pasien meninggal (47,5\%). Perbandingan antara kelompok hidup dan meninggal menunjukan perbedaan bermakna dan secara signifikan berhubungan dengan mortalitas pada SOFA score hari ke-5 $(p<0,001 ;$ OR: 78,75, Cl 95\% (9,948-623,414)), kadar IL-6 hari ke-5 ( $p<0,05$; OR: 9,208, Cl 95\% $(2,146-39,521)$ ) dan kadar PCT hari ke-5 ( $p<0,05 ;$ OR: 4,190, Cl 95\% (1,104-15,901)). Hasil uji regresi logistik, didapatkan bahwa IL-6 hari ke-5 dan SOFA score hari ke-5 dapat digunakan sebagai faktor prognostik mortalitas pasien pneumonia dengan sepsis hari ke-30, artinya SOFA score diatas 6 dan kadar IL-6 diatas $332 \mathrm{pg} / \mathrm{mL}$ pada hari ke-5, merupakan faktor penting dari kematian pasien (AUC: 0,935).
\end{abstract}

Kata Kunci: Interleukin-6, mortalitas, pneumonia dengan sepsis, prokalsitonin, SOFA score

\begin{abstract}
Pneumonia is the top ten largest cases of hospitalization in Indonesia with 7.6\% Crude Fatality Rate. Septic pneumonia patients need supportive therapy and intensive care because of the high mortality rate. Early diagnostic and prognostic assessment are needed for improving the treatment quality and better outcome. Procalcitonin (PCT) and Interleukin-6 (IL6) are indicators of infection and sepsis. This study aimed to analyze whether PCT and IL-6 can be used together to determine the prognostic value of septic pneumonia in relation to the thirtieth-day mortality status. Cohort study done at Saiful Anwar General Hospital involved 40 septic pneumonia patients without diabetic, cancer, HIV, and pregnancy. Sequential Organ Failure Assesment (SOFA) score was also calculated and blood samples were collected at zero and fifth day for measuring PCT and IL-6 value. at the same time. The thirtieth-day mortality status was confirmed after admission. From 40 subjects, 23 subjects were survivors (57.5\%), and 17 subjects were non-survivors (42.5\%). The comparison between survivor and non-survivor showed significant difference and related with mortality in SOFA score day-5 ( $p<0.001$; OR: 78.75, CI 95\% (9.948-623.414)), IL-6 level day-5 ( $p<0.05$; OR: 9.208, Cl 95\% (2.146-39.521)) and PCT day-5 ( $p<0.05 ;$ OR: 4.190, CI 95\% (1.104-15.901)). The logistic regression test results show that IL-6 on day-5 and SOFA score on day-5 can be used as mortality prognostic markers in septic pneumonia patient on day-30, it means that SOFA score above 6 and IL-6 level above $322 \mathrm{pg} / \mathrm{mL}$ in day-5 have a significant role in patient mortality (AUC: 0.935).
\end{abstract}

Keywords: Interleukin-6, mortality, procalcitonin, septic pneumonia, SOFA score

Korespondensi: Sylvia Sagita S. Departemen Pulmonologi dan Kedokteran Respirasi Rumah Sakit Umum Daerah Dr. Saiful Anwar Malang, Jl. Jaksa Agung Suprapto No. 2, Malang Tel.081378066578Email: sylvie.aesculapius@gmail.com

DOI: http://dx.doi.org/10.21776/ub.jkb.2019.030.04.6 


\section{PENDAHULUAN}

Sepsis merupakan kondisi disfungsi organ yang mengancam jiwa yang disebabkan oleh disregulasi respon tubuh terhadap infeksi dan berhubungan dengan mortalitas, sehingga memerlukan terapi yang adekuat dan tepat. Sumber infeksi sepsis dapat berasal dari genitourinarius, abdomen, kulit, jaringan lunak, infeksi akibat penggunaan alat medis, susunan saraf pusat dan endokarditis (1). Pneumonia adalah peradangan akut parenkim paru yang disebabkan oleh mikroorganisme antara lain bakteri, virus, jamur, parasit. Pneumonia menyerang sekitar 450 juta orang per tahun di seluruh belahan dunia dan menjadi penyebab utama kematian di antara semua kelompok usia dengan menghasilkan 4 juta kematian (7\% dari total tahunan dunia) (2). Insiden dan kegawatan sepsis mendorong peneliti untuk menelaah nilai prognostik dengan penggunaan penanda terhadap pasien pneumonia dengan sepsis.

Penggunaan penanda telah banyak digunakan dan menjadi hal yang penting pada manajemen pasien. Prinsip penanda pada kondisi sepsis yaitu untuk mengeksklusi dan mengidentifikasi adanya infeksi, sebagai penanda berat ringannya sepsis untuk triase pasien dan pemberian terapi awal, serta dapat digunakan untuk mengevaluasi klinis pasien untuk pemberian terapi lanjutan (3). Kriteria Sequential Organ Failure Assesment (SOFA) score merupakan salah satu penanda yang digunakan untuk mengenali pasien dalam kondisi sepsis dengan disfungsi organ secara klinis. Skor SOFA terdiri dari 6 kriteria yaitu, respirasi, koagulasi, hati, kardiovaskuler, susunan saraf pusat dan ginjal. Infeksi saluran nafas terutama pneumonia merupakan penyebab utama sepsis. Pemeriksaan Prokalsitonin (PCT) merupakan penanda inflamasi dan infeksi berperan penting terutama pada infeksi bakteri berat, sepsis, syok septik, dan sindrom disfungsi multiorgan (MODS) bila didapatkan kadar PCT lebih dari $2 \mu \mathrm{g} / \mathrm{L}$. Kadar PCT 0,25-0,5 $\mu \mathrm{g} / \mathrm{L}$ merupakan panduan untuk memulai pemberian antibiotika dan pemberian antibiotika tersebut dapat dihentikan bila kadar PCT menurun $>80-90 \%$ atau kadar PCT $<0,25 \mu \mathrm{g} / \mathrm{L}$ (pasien dirawat ruang biasa) atau $<0,5 \mu \mathrm{g} / \mathrm{L}$ (pasien dirawat ruang intensif), dengan nilai $0,5 \mu \mathrm{g} / \mathrm{L}$ setara dengan $500 \mathrm{pg} / \mathrm{mL}$. Hal ini bermanfaat untuk mempersingkat waktu penggunaan antibiotika sehingga dapat menurunkan efek samping dan resistensi, serta mengurangi biaya dan lama perawatan (2).

Interleukin-6 (IL-6) merupakan sitokin pleiotropik dengan akivitas biologik yang luas terhadap regulasi imun, hematopoiesis, inflamasi dan onkogenesis. Pemilihan IL-6 diantara sitokin inflamasi lain berdasarkan perkembangannya yang cepat terdeteksi di plasma ketika muncul rangsangan inflamasi. Disamping itu secara teknis dan ketersediaan kit pemeriksaan IL-6 lebih mudah, serta dapat terdeteksi dengan mudah dibanding dengan sitokin lain. IL-6 dapat terdeteksi pada awal respon host terhadap infeksi dan IL-6 dapat merangsang migrasi dari sel limfosit T yang teraktivasi secara in vitro (4), dan telah tervalidasi menjadi faktor risiko derajat berat ringannya sepsis pada pasien perawatan intensif. Kadar puncak IL-6 dengan SOFA score dapat meningkatkan prediksi mortalitas pada pasien sepsis (5). Berdasarkan kajian tersebut penelitian ini dilakukan untuk menelaah kadar PCT dan IL-6 pada pasien pneumonia dengan sepsis berdasarkan kriteria SOFA score.

\section{METODE}

Penelitian dilakukan dengan desain Cohort Prospective Study menggunakan sumber data dari pasien pneumonia dengan sepsis yang dirawat di ruang intensif. Populasi penelitian adalah pasien pneumonia dengan sepsis yang dirawat inap di Respiratory High Care Unit/Intensive Care Unit (RHCU/ICU) RS Saiful Anwar Malang. Sampel diperoleh dengan cara consecutive sampling yaitu pasien pneumonia dengan sepsis yang memenuhi kriteria inklusi yaitu pasien pneumonia dengan sepsis usia 18-80 tahun dan bersedia ikut penelitian dan menandatangani "informed consent". Pasien dengan HIV-AIDS, kanker atau dalam pengobatan imunosupresan, diabetes mellitus dan hamil dieksklusi dari penelitian ini. Pasien yang meninggal dunia sebelum hari kelima perawatan rumah sakit merupakan kriteria drop out. Subjek penelitian berjumlah 40 pasien pneumonia dengan sepsis (SOFA $\geq 2$ ), dilakukan pengambilan sampel darah dan dinilai SOFA score hari-0 dan hari-5. Selanjutnya dilakukan pemeriksaan kadar PCT dan IL-6 menggunakan ELISA kit (Cusabio untuk PCT dan Legend Max untuk (L-6) dengan tehnik quantitative sandwich enzyme immunoassay. Perkembangan pasien diikuti hingga hari ke-30. Seluruh data penelitian dilakukan uji Chi-square untuk menentukan hubungan antar variabel. Untuk uji prognostik, dilakukan penentuan cutoff, kemudian dilanjutkan dengan analisa deskriptif, analisis bivariat serta analisis multivariat. Data uji prognostik diambil dari data.

\section{HASIL}

Penelitian ini melibatkan sampel sebanyak 40 orang, yaitu 28 orang laki-laki dan 12 orang perempuan (Tabel 1). Pasien yang meninggal pada hari ke-30 berjumlah 17 orang, sedangkan pasien yang masih hidup di hari ke-30 sejumlah 23 orang. Ada 13 pasien yang meninggal sebelum hari ke-5 (masuk kriteria drop out). Berdasarkan distribusi usia pasien antara 18-80 tahun, didapatkan jumlah terbanyak pada rentang usia 51-65 tahun yaitu 15 pasien dan rentang usia 66-80 tahun sebanyak 17 pasien.

Tabel 1. Karakteristik sosiodemografi

\begin{tabular}{llcc}
\hline \multirow{2}{*}{ Karakteristik } & Survivor & $\begin{array}{c}\text { Non } \\
\text { Survivor }\end{array}$ \\
\hline \multirow{3}{*}{ Usia } & Minimum & 29 & 18 \\
& Maksimum & 80 & 80 \\
\multirow{3}{*}{ Status Perkawinan Kelamin } & Laki-laki & 15 & 13 \\
& Perempuan & 8 & 4 \\
Status Merokok & Kawin & 2 & 1 \\
& Belum Kawin & 21 & 16 \\
Pendidikan & Ya & 15 & 13 \\
& Tidak & 8 & 4 \\
& SD & 6 & 7 \\
Pekerjaan & SMP & 12 & 7 \\
& SMA & 5 & 3 \\
& Pelajar & - & 1 \\
& Pedagang & 3 & 4 \\
& Swasta & 3 & - \\
& Petani & 4 & 5 \\
& IRT & 8 & 4 \\
& Pensiunan & 5 & 3 \\
\hline
\end{tabular}

Dari 40 pasien, berhasil diperoleh 33 hasil kultur darah dan kultur sputum, 7 sampel tidak ditemukan hasil kultur karena kesulitan dalam proses pengambilan sampel. Etiologi pneumonia dari hasil kultur sputum pada penelitian ini, paling banyak adalah Staphylococcus 
coagulase negative (SCN) (12 pasien); kemudian jamur (6 pasien); Klebsiella pneumonia (4 pasien); Pseudomonas aeruginosa (4 pasien); Acinetobacter baumanii (3 pasien); Serratia liquefasiens, Streptococcus mitis, Pantoea spp dan Achromobacter xylooxidans masing-masing sebanyak 1 pasien. Dari 33 sampel kultur darah, hanya 1 sampel yang memiliki hasil kultur darah positif dengan temuan Staphylococcus cohnii.

Penilaian SOFA score ditetapkan dengan nilai cut off 6 . Berdasarkan uji Chi-square, tidak ada hubungan yang signifikan antara SOFA score hari-0 dengan mortalitas pada pasien (OR: 3,438; Cl 95\%=0,924-12,787). Meskipun demikian, terdapat hubungan signifikan antara SOFA score hari-5 dengan tingkat mortalitas pasien (OR: 78,75; $\mathrm{Cl} 95 \%=9,948-623,414)$. Pasien dengan SOFA score $\geq 6$ pada hari-5 lebih berisiko mengalami kematian dibandingkan SOFA score <6 (Tabel 2).

Dengan cut off PCT pada $0,5 \mu \mathrm{g} / \mathrm{L}$ uji Chi-Square menunjukkan bahwa tidak ada hubungan antara kadar PCT serum hari-0 dengan mortalitas (OR: 2,2; CI $95 \%=0,584-8,283)$. Didapatkan hubungan signifikan antar kadar PCT hari-5 dengan mortalitas pasien (OR: 4,190; Cl $95 \%=1,104-15,901)$. Pasien dengan kadar PCT $\geq 0,5 \mu \mathrm{g} / \mathrm{L}$ pada hari-5 memiliki risiko lebih tinggi untuk mengalami kematian dibandingkan pasien dengan kadar PCT $<0,5 \mu \mathrm{g} / \mathrm{L}$ (Tabel 2).

Data cut-off IL-ditetapkan pada nilai $601 \mathrm{pg} / \mathrm{mL}$ untuk hari0 dengan sensitivitas $58.8 \%$ dan spesifitas $60.9 \%$ (AUC Cl 95\%: 0,692 (0,529-0,854). Untuk pemeriksaan pada hari ke 5 ditetapkan cut-off IL-6 pada nilai 332pg/mL dengan sensitivitas 76,5\% dan spesifitas 78.3\% (AUC CI 95\%: 0,829 $(0,700-0,857)$. Berdasarkan hasil uji chi-square tidak ditemukan hubungan yang signifikan antara kadar IL-6 hari-0 pasien dengan mortalitas (OR: 3,$438 ; \mathrm{Cl}$ $95 \%=0,924-12,787)$. Disisi lain ditemukan hubungan yang bermakna antara kadar IL-6 hari-5 dengan mortalitas pasien (OR: 9,208; Cl 95\%=2,146-39,521). Pasien dengan kadar IL-6 $\geq 322 \mathrm{pg} / \mathrm{mL}$ pada hari ke-5 mempunyai risiko mortalitas pada hari-30 yang lebih tinggi (Tabel 2 ).

Tabel 2. Data SOFA score, PCT, IL-6

\begin{tabular}{|c|c|c|c|c|c|c|}
\hline \multirow{2}{*}{\multicolumn{2}{|c|}{ Penanda }} & \multicolumn{2}{|c|}{ Hidup } & \multicolumn{2}{|c|}{ Meninggal } & \multirow{2}{*}{ p } \\
\hline & & $\mathrm{Jml}$ & $\%$ & $\mathrm{Jml}$ & $\%$ & \\
\hline \multirow{2}{*}{ SOFA score hari-0 } & $<6$ & 15 & 71,428 & 6 & 28,571 & \multirow{2}{*}{0,061} \\
\hline & $\geq 6$ & 8 & 42,105 & 11 & 57,894 & \\
\hline \multirow{2}{*}{ SOFA score hari-5 } & $<6$ & 21 & 91,304 & 2 & 8,6956 & \multirow{2}{*}{$<0,001$} \\
\hline & $\geq 6$ & 2 & 11,764 & 15 & 88,235 & \\
\hline \multirow{2}{*}{ PCT hari-0 } & $<0,5 \mu \mathrm{g} / \mathrm{L}$ & 11 & 68,75 & 5 & 31,25 & \multirow{2}{*}{0,24} \\
\hline & $\geq 0,5 \mu \mathrm{g} / \mathrm{L}$ & 12 & 50 & 12 & 50 & \\
\hline \multirow{2}{*}{ PCT hari-5 } & $<0,5 \mu \mathrm{g} / \mathrm{L}$ & 16 & 72,727 & 6 & 27,272 & \multirow{2}{*}{0,031} \\
\hline & $\geq 0,5 \mu \mathrm{g} / \mathrm{L}$ & 7 & 38,888 & 11 & 61,111 & \\
\hline \multirow{2}{*}{ IL-6 hari-0 } & $<601 \mathrm{pg} / \mathrm{mL}$ & 17 & 65,384 & 9 & 34,615 & \multirow{2}{*}{0,061} \\
\hline & $>601 \mathrm{pg} / \mathrm{mL}$ & 6 & 42,857 & 8 & 57,142 & \\
\hline \multirow{2}{*}{ IL-6 hari-5 } & $<332 \mathrm{pg} / \mathrm{mL}$ & 21 & 67,741 & 10 & 32,258 & \multirow{2}{*}{$0,002^{i}$} \\
\hline & $\geq 332 \mathrm{pg} / \mathrm{mL}$ & 2 & 22,222 & 7 & 77,777 & \\
\hline
\end{tabular}

Analisis regresi logistik dengan metode backward stepwise digunakan setelah dilakukan uji beda, untuk mengetahui variabel yang memiliki nilai prognostik. Sesuai dengan syarat analisa multivariat yaitu variabel dengan nilai $p<0,25$ pada analisa bivariat, pada uji regresi logistik variabel yang dianalisis meliputi SOFA score hari-0,
IL-6 hari-0, dan PCT hari-0. Dari uji prognostik ini didapatkan, variabel yang memiliki nilai prognostik pada hari ke-0 adalah IL-6, namun nilai Area Under Curve (AUC) dari kurva Receiver Operating Characteristic (ROC) hanya $65 \%$, sehingga hasil belum dapat diterima (Gambar 2).

Nilai prognostik dicari menggunakan uji regresi logistik dengan metode backward stepwise. Variabel yang dapat dimasukan ke dalam uji multivariat adalah SOFA score hari5, IL-6 hari-5 dan PCT hari-5. Hasil menunjukkan bahwa variabel yang memiliki nilai prognostik adalah SOFA Score hari-5 dan IL-6 hari-5, dengan persamaan $y=3.083-2.211$ (IL-6 hari-5) - 4.361 (SOFA Score hari-5). Berdasarkan persamaan tersebut mortality rate pasien dapat dihitung dengan $p=\frac{1}{1+\exp (-y)}$. Analisa Hasmer and Lemeshow menunjukkan bahwa model terkalibrasi dengan baik $(p=0,511)$. Dengan cut off yang ditetapkan, nilai AUC termasuk dalam kategori baik (kurva ROC 94,8\%), artinya jika model tersebut digunakan untuk menentukan prognosis pada 100 orang pasien, maka kesimpulan yang tepat akan diperoleh pada 94 orang pasien (Gambar 2).

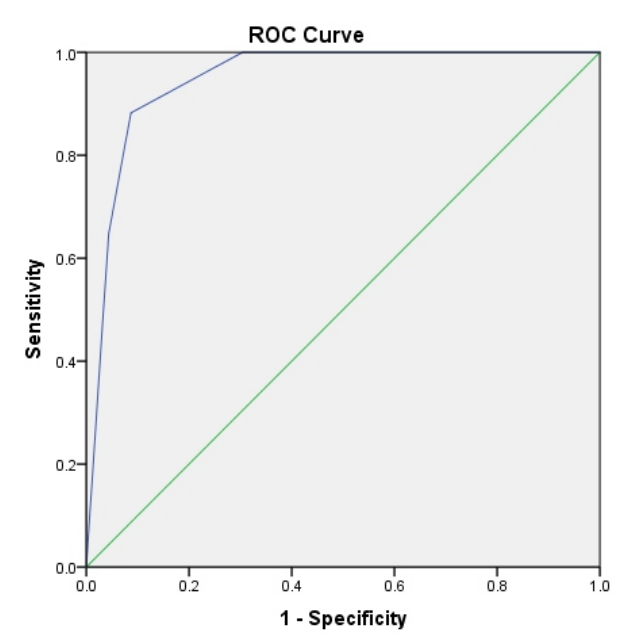

Gambar 2. Kurva ROC hari-5

\section{DISKUSI}

Hasil penelitian ini menunjukkan bahwa penderita pneumonia yang diteliti lebih banyak berjenis kelamin lakilaki dibandingkan dengan wanita serta lebih banyak pada usia 66-88 tahun. Penelitian Rivero-Calle et al, menemukan hasil yang sama bahwa prevalensi pneumonia di Spanyol lebih banyak pada laki-laki dibandingkan wanita (51,7\% dibandingkan 48,3\%) (6). Kejadian pneumonia meningkat seiring bertambahnya usia, dan lebih dari $90 \%$ kematian akibat pneumonia berat terjadi pada pasien berusia di atas 70 tahun. Penelitian prevalensi di Amerika Selatan pada tahun 2012-2015 juga menemukan bahwa pneumonia paling banyak dialami oleh kelompok usia $\geq 65$ tahun (7).

\section{Hubungan SOFA Score dengan Mortalitas}

Hasil penelitian ini menunjukkan terdapat perbedaan yang signifikan pada SOFA score (dengan cut off 6) pada hari-5, namun tidak pada hari ke- 0 . Pasien dengan SOFA Score $\geq 6$ lebih berisiko mengalami kematian dibandingkan pasien dengan SOFA score <6 (OR: 78,75; CI 95\%=9,948-623,414). Penelitian Jones et al, pada tahun 2009 menggunakan SOFA score untuk memprediksi keluaran pasien dengan 
sepsis berat pada saat pasien masuk (hari-0) dan 72 jam setelah masuk ruang intensif menemukan hasil yang berbeda. Rerata yang ditemukan oleh Jones et al, pada hari-0 dan 72 jam setelah masuk ruang intensif sebesar $7,1 \pm 3,6$ dan $7,4 \pm 4,9$. dari analisis daerah di bawah kurva ROC, SOFA score pada hari-0 dan 72 jam setelah masuk ruang intensif sebesar 0,75 dan 0,84 . Nilai SOFA score pada kedua waktu tersebut memiliki hubungan positif dengan mortalitas di dalam rumah sakit. Studi oleh Jones et al, tersebut dilakukan pada pasien dengan sepsis berat, bukan pada pasien yang mengalami sepsis hanya akibat pneumonia (8) yang menjelaskan perbedaan dengan temuan pada penelitian ini.

Beberapa penelitian sebelumnya menunjukkan bahwa perbedaan skor SOFA sudah terjadi sejak 24 jam pertama. Penelitian yang dilakukan oleh Raith et al, menunjukkan bahwa SOFA score yang dihitung dalam 24 jam pertama pasien masuk di ruang intensif memiliki akurasi prediksi lebih baik dibandingkan dengan qSOFA dan kriteria SIRS (9). Disamping itu penelitian yang dilakukan oleh Lie et al, tentang penggunaan SOFA score yang dihitung pada saat pasien rawat inap dalam prediksi mortalitas akibat sepsis pada pasien sepsis di Asia Tenggara menemukan bahwa SOFA score pada pasien yang meninggal lebih tinggi dibandingkan dengan SOFA score pada pasien yang bertahan hidup (10).

\section{Hubungan PCT dengan Mortalitas}

Hasil penelitian ini menunjukkan terdapat perbedaan yang signifikan pada kadar PCT (dengan cut off $0,5 \mu \mathrm{g} / \mathrm{L}$ ) pada hari ke- 5 untuk kelompok pasien pneumonia dengan sepsis yang meninggal dibandingkan dengan yang hidup (OR: 4,190; Cl 95\%=1,104-15,901) namun tidak terdapat perbedaan pada hari-0. Pasien dengan kadar PCT $\geq 0,5 \mu \mathrm{g} / \mathrm{L}$ yang ditemukan pada hari ke-5 memiliki risiko lebih tinggi untuk mengalami kematian dibandingkan pasien dengan kadar $\mathrm{PCT}<0,5 \mu \mathrm{g} / \mathrm{L}$. Meta analisis dari 21 penelitian dengan 6.007 pasien menemukan bahwa peningkatan kadar PCT menjadi faktor resiko mortalitas pada pneumonia, terutama pasien dengan nilai CURB-65 rendah. Meskipun demikian, kadar PCT dengan nilai cutoff $<0,5 \mu \mathrm{g} / \mathrm{L}$ memiliki sensitivitas rendah dan tidak dapat mengidentifikasi pasien dengan risiko mortalitas tinggi. Untuk penilaian prognostik tersebut terbatas pada pasien dengan pneumonia (11).

\section{Hubungan IL-6 dengan Mortalitas}

Untuk kadar IL-6 dilakukan penentuan cut-off pada hari-0 dan hari-5, karena ditemukan kadar yang sangat bervariasi. Data IL-6 hari-0 dibagi menjadi $<601 \mathrm{pg} / \mathrm{mL}$ dan $\geq 601 \mathrm{pg} / \mathrm{mL}$ (sensitivitas 58,8\%, spesifitas 60,9\%), sedangkan data IL-6 hari-5, dibagi menjadi $<332 \mathrm{pg} / \mathrm{mL}$ dan $\geq 332 \mathrm{pg} / \mathrm{mL}$ (sensitivitas $76,5 \%$, spesifitas 78,3\%). Hasil penelitian ini menunjukkan terdapat perbedaan yang signifikan pada IL-6 hari-5 untuk kelompok pasien pneumonia dengan sepsis yang meninggal dibandingkan

\section{DAFTAR PUSTAKA}

1. Singer $\mathrm{M}$, Deutschman $\mathrm{CS}$, Seymour CW, et al. The Third International Consensus Definitions for Sepsis and Septic Shock (Sepsis-3). Jounal of the American Medical Association. 2016; 315(8): 801-810.

2. Perhimpunan Dokter Paru Indonesia. Pneumonia Komunitas. (OnI i e ) 2014 . dengan yang hidup (OR: 9,208; $\mathrm{Cl} 95 \%=2,146-39,521)$. Meskipun demikian, IL-6 hari-0 tidak memiliki hubungan yang signifikan terhadap tingkat mortalitas pasien.

Hasil penelitian ini sesuai dengan studi Bayarri et al, yang mengemukakan bahwa IL-6 merupakan penanda sepsis sebagai prediktor mortalitas terutama setelah 3 hari perawatan dibandingkan dengan skor Acute Physiologiy and Chronic Health Evaluation (APACHE II) (12). Studi Nafaa et al, juga mendukung hasil penelitian ini yang menunjukkan bahwa kadar IL-6 yang tinggi pada saat pasien keluar rumah sakit berhubungan dengan peningkatan mortalitas selama 6 bulan kedepan. Jika dibandingkan dengan kadar IL-6 pada awal pasien masuk rumah sakit, kadar IL-6 saat pasien keluar rumah sakit merupakan prediktor yang lebih baik terhadap segala penyebab kematian pada pasien sepsis (13).

\section{Uji Prognostik}

Dari hasil analisis multivariat uji linier regresi pada hari-5 didapatkan variabel yang memiliki nilai prognostik pada hari ke-5 adalah SOFA score dan IL-6. Hanya beberapa penelitian sebelumnya yang telah membahas potensi prognostik dari nilai konsentrasi plasma IL- 6 pada pasien sepsis. Identifikasi sepsis pada pasien dengan inflamasi sistemik sangat penting untuk implementasi terapi akut dan spesifik secara tepat waktu termasuk penanganan dini antibiotik dan source control. Dalam studi Mat-Nor et al, disebutkan bahwa PCT lebih akurat daripada IL-6 dalam mendiagnosis sepsis, dengan puncak AUC 0,69 (95\% Cl, $0,63-0,76)$. Perbedaannya dengan penelitian ini hanya konsentrasi IL- 6 hari-1 yang lebih tinggi pada kelompok sepsis, namun, AUC lebih rendah $(0,58 ; 95 \% \mathrm{Cl}, 0,51-0,66)$. Kadar PCT dikaitkan dengan tingkat keparahan yang meningkat terhadap infeksi bakteri dan menunjukkan signifikansi statistik antara SIRS, sepsis berat, dan kelompok syok sepsis. Hal ini menunjukkan bahwa IL-6 memprediksi angka kematian lebih baik dari PCT dan sebagai nilai tambah pada skor SOFA. Hasil studi ini sesuai dengan penelitian ini dimana terdapat model prognostik kombinasi kadar IL-6 dan SOFA score hari ke-5 (13).

SOFA score $\geq 6$, kadar PCT $\geq 0,5 \mu \mathrm{g} / \mathrm{L}$ dan kadar IL-6 $\geq 322 \mathrm{pg} / \mathrm{mL}$ pada hari ke-5 meningkatkan mortalitas pasien pneumonia dengan sepsis. SOFA score, kadar PCT dan IL- 6 hari ke-0 tidak dapat memprediksi mortalitas pasien dalam 30 hari pada kasus pneumonia dengan sepsis. SOFA score dan kadar IL-6 pada hari ke-5 dapat digunakan untuk memprediksi mortalitas pasien dalam 30 hari pada kasus pneumonia dengan sepsis. Penelitian lebih lanjut dapat dilakukan untuk mengkaji dinamika perubahan dalam SOFA score, kadar PCT dan kadar IL-6 dalam memprediksi mortalitas pasien. Penelitian serupa juga dapat dilakukan dengan tujuan lain, seperti penerapan percobaan gabungan dengan multi-penanda dan uji coba multi senter untuk mengkaji peran penanda dalam memprediksi kekambuhan penyakit atau terjadinya perawatan ulang pasien.

http://www.klikpdpi.com/konsensus/konsensuspneumoniakom/pnkomuni-ti.pdf. [diakses pada tanggal 12 Desember 2017].

3. Vincent JL and Teixeira L. Sepsis Penandas Value and Limitations. American Journal of Respiratory Critical Care Medicine. 2014; 190(10): 10811082. 
4. Pallás BLA, Rodríguez LO, Saiz SC, Coltell O, Bautista RD, and Miguel BV. Prognostic Value of IL-6 for Death of Patients with Sepsis. Medicina Clinica. 2016; 147(7): 281-282.

5. Mat-Nor MD, Ralib A, Abdulah NZ, Pickering JW. The Diagnostic Ability of Procalcitonin and Interleukin-6 to Differentiate Infectious from Non-infectious Systemic Inflammatory Response Syndrome and to Predict Mortality. Journal of Critical Care. 2016; 33: 245-251.

6. Rivero-Calle I, Pardo-Seco J, Aldaz P et al. Incidence and Risk Factor Prevalence of Community-Acquired Pneumonia in Adults in Primary Care in Spain (NEUMO-ES-RISK Project). BioMed Central Infectious Disease. 2016; 16(1): 645-652.

7. Lopardo GD, Fridman D, Raimondo $\mathrm{E}$, et al. Incidence Rate of Community Acquired Pneumonia in Adults: A Population Based Prospective Active Surveillance Study in Three Cities South America. British Medical Journal Open. 2018; 8(4): 1-9.

8. Jones AE, Trzeciak S, Kline JA. The Sequential Organ Failure Assessment Score for Predicting Outcome in Patients with Severe Sepsis and Evidence of Hypoperfusion at the Time of Emergency Department Presentation. Critical Care Medicine
2009; 37(5): 1649-1654.

9. Raith EP, Udy AA, Bailey M, et al. Prognostic Accuracy of the SOFA Score, SIRS Criteria, and qSOFA Score for In-Hospital Mortality among Adults with Suspected Infection Admitted to the Intensive Care Unit. Jounal of the American Medical Association. 2017; 317(3): 290-300.

10. Lie KC, Lau CY, Chau NVV, West TE, and Limmathurotsakul D. Utility of SOFA Score, Management and Outcomes of Sepsis in Southeast Asia: A Multinational Multicenter Prospective Observational Study. Journal Intensive Care. 2018; 6: 9.

11. Liu V, Escobar GJ, Greene JD, et al. Hospital Deaths Inpatients with Sepsis from Two Independent Cohorts. Jounal of the American Medical Association. 2014; 312(1): 90-92.

12. Bayarri VM, Laparra EBC, Beneyto LP, et al. Prognostic Value of the Biomarkers Procalcitonin, Interleukin-6, and C-Reactive Protein in Severe Sepsis. Medicina Intensiva. 2012; 36(8): 556-562.

13. Naffaa M, Makhoul BF, Tobia A, et al. Interleukin-6 at Discharge Predicts All-Cause Mortality in Patients with Sepsis. The American Journal of Emergency Medicine. 2013;31(9): 1361-1364. 